\title{
Kroniek
}

\section{Kroniek civiele rechtspraak mededingingsrecht 2020}

\author{
Marianne Meijssen en Stefan Tuinenga*
}

\section{Inleiding}

In deze kroniek bespreken wij de mededingingsrechtelijke uitspraken van de Nederlandse civiele rechter in 2020. Wij telden in totaal 26 zaken die kwalificeren voor deze kroniek. ${ }^{1}$ Dat is een magere oogst in vergelijking met de 41 zaken van vorig jaar. Er zijn met name minder follow-on zaken in het meest recente kroniekjaar. ${ }^{2}$ De komende jaren zullen uitwijzen of dit een trendbreuk is.

Ook de Europese ontwikkelingen waren beperkter dan het jaar ervoor, toen het Hof van Justitie enkele baanbrekende arresten wees in Skanska, Otis, Tibor-Trans en Cogeco. ${ }^{3}$ Dit jaar moeten we het doen met twee belangwekkende arresten over internationale bevoegdheid in de zaken Volkswagen ${ }^{4}$ en Booking.com. ${ }^{5}$ Wel heeft de

Mr. M.A. Meijssen is advocaat bij Scott+Scott. Mr. S. Tuinenga is advocaat bij Scott+Scott. De auteurs zijn in een aantal van de besproken zaken betrokken of betrokken geweest als advocaat. Dit artikel is geschreven op persoonlijke titel.

1. Vijf gepubliceerde follow-on zaken en 21 gepubliceerde standalone civiele mededingingsrechtzaken met een inhoudelijke beoordeling (exclusief staatssteunzaken).

2. Onder follow-on zaken scharen auteurs ook zogenoemde hybride zaken, waarin zowel een beroep wordt gedaan op een besluit van een mededingingsautoriteit als aanvullende feiten gesteld worden.

3. HvJ EU 14 maart 2019, zaak C-724/17, ECLI:EU:C:2019:204 (Skanska), HvJ EU 12 december 2019, zaak C-435/18, ECLI:EU:C:2019:1069 (Otis), HvJ EU 29 juli 2019, zaak C-451/18, ECLI:EU:C:2019:635 (Tibor-Trans), HvJ EU 28 maart 2019, zaak C-637/17, ECLI:EU:C: 2019:263 (Cogeco)

4. HvJ EU 9 juli 2020, zaak C-343/19, ECLI:EU:C:2020:534 (Verein fur Konsumenteninformation - Volkswagen AG)

5. HvJ EU 24 november 2020, zaak C-59/19, ECLI:EU:C:2020:950 (Wikingerhof GmbH \& Co. KG - Booking.com).
Nederlandse rechter in het afgelopen jaar Europese arresten uit 2019 in verschillende zaken toegepast, onder meer in het kader van verjaring.

Een andere Europese ontwikkeling die wij benoemen, is Brexit. De Brexit-transitieperiode is met het einde van dit kroniekjaar geëindigd op 31 december 2020. Aldus is de Europese Commissie vanaf 1 januari 2021 niet meer bevoegd voor mededingingszaken in het Verenigd Koninkrijk. ${ }^{6}$ Wij verwachten dat door Brexit meer Europese follow-on kartelzaken in Nederland aangebracht zullen worden, als alternatief forum voor het Verenigd Koninkrijk. ${ }^{7}$

Op het gebied van nieuwe regelgeving hebben wij vorig jaar de verwachting uitgesproken dat de per 1 januari 2020 in werking getreden Wet afwikkeling massaschade in collectieve actie (WAMCA) ${ }^{8}$ tot mededingingsrechtelijke uitspraken gaat leiden. Hoewel voor grotere kartelschadeclaims het zogenoemde 'cessiemodel' inmiddels breed geaccepteerd is (zie nader onder 'rechtsgeldigheid cessies'), kan de WAMCA (met haar opt-out regime) met name toegevoegde waarde hebben voor het verhaal van strooischade, welke vaak door consumenten wordt geleden. Het afgelopen jaar leert dat dit nog wel enig tijd kan duren. Geen van de tot dusver ingeschreven zaken heeft immers een mededingingsrechtelijke aard. ${ }^{9}$

6. Competition (Amendment) (EU Exit) Verordeningen 2020 (S 2020/1343)

7. Zie ook: N.M.L. Dhondt, 'Wat betekent Brexit voor het mededingingsrecht? De EU-VK-handels- en samenwerkingsovereenkomst', MP 2021-1, p. 16.

8. Wijziging van het Burgerlijk Wetboek en het Wetboek van Burgerlijke Rechtsvordering teneinde de afwikkeling van massaschade in een collectieve actie mogelijk te maken (Wet afwikkeling massaschade in collectieve actie)

9. www.rechtspraak.nl/Registers/centraal-register-voor-collectievevorderingen. 
Ondanks deze kanttekeningen heeft 2020 meer dan voldoende stof opgeleverd voor een gevarieerde kroniek, met een bespreking van procedurele kwesties als bevoegdheid, cessies en verjaring, alsook inhoudelijke beoordelingen over onder meer misbruik machtspositie, selectieve distributie en verhaal van een kartelboete op een bestuurder.

\section{Follow-on zaken}

\section{Bevoegdheid}

$\mathrm{Na}$ het vorig jaar besproken Tibor-Trans-arrest zijn de Europese bevoegdheidsregels met betrekking tot verbintenissen uit onrechtmatige daad, in het bijzonder het Erfolgsort als de plaats waar de schade zich heeft voorgedaan, in 2020 wederom aan de orde gekomen bij het Hof van Justitie. Dit keer na prejudiciële verwijzingen van de Duitse en Oostenrijkse rechter in de Booking.com- en Volkswagen-zaken.

In de zaak Booking.com draait het om het onderscheid in bijzondere bevoegdheidsregels voor een vordering uit overeenkomst (art. 7 lid 1 EEX-Verordening) en uit onrechtmatige daad (art. 7 lid 2 EEX-Verordening). ${ }^{10}$ Het Duitse hotel Wikingerhof had een vordering op basis van onrechtmatige daad ingesteld tegen Booking.com, omdat deze partij misbruik zou hebben gemaakt van haar machtspositie door onredelijke voorwaarden aan Wikingerhof op te leggen. Booking.com verweerde zich met het standpunt dat niet de rechter in Duitsland (het Erfolgsort volgens Wikingerhof), maar de rechter in Nederland bevoegd was omdat het een uit een overeenkomst voortvloeiend geschil betrof. ${ }^{11}$ De Duitse rechter legde vervolgens aan het Hof van Justitie de vraag voor of de bevoegdheid in deze zaak vastgesteld kon worden op basis van het Erfolgsort van artikel 7 lid 2 EEX-Verordening.

Het Hof van Justitie antwoordt bevestigend. Allereerst bevestigt het Hof van Justitie dat de begrippen 'verbintenissen uit onrechtmatige daad' en 'verbintenissen uit overeenkomst' autonoom dienen te worden uitgelegd, en niet verwijzen naar de kwalificatie die de toepasselijke nationale wet geeft aan de rechtsbetrekking. ${ }^{12}$ De toepasselijkheid van artikel 7 lid 1 dan wel lid 2 EEXVerordening hangt allereerst af van de keuze van de eiser om zich op een van deze grondslagen te beroepen, aldus het Hof van Justitie. Ten tweede dient de rechter onderzoek te doen of er daadwerkelijk sprake is van de door de eiser aangevoerde grondslag. ${ }^{13}$ Het Hof van Justitie oordeelt dat het relevante onderscheid moet worden gevonden in de beantwoording van de vraag of het nodig

10. Wikingerhof $\mathrm{GmbH} \&$ Co. $\mathrm{KG}-$ Booking.com

11. Het Bundesgerichtshof had al geoordeeld dat het forumkeuzebeding in de overeenkomst niet rechtsgeldig was, de toepasselijkheid daarvan lag aldus niet voor bij het Hof van Justitie, zie r.o. 14. Zie over de rechtsgeldigheid van forumkeuzebedingen bij misbruik van machtspositiezaken HvJ EU 24 oktober 2018, zaak C-595/17, ECLI:EU:C:2018:854 (Apple Sales International c.s. $-M J A$ ).

12. Wikingerhof $\mathrm{GmbH} \&$ Co. $\mathrm{KG}-$ Booking.com, r.o. 25.

13. Wikingerhof GmbH \& Co. $K G-$ Booking.com, r.o. 29. is om de inhoud van de overeenkomst te onderzoeken om te bepalen of een gedraging geoorloofd is. Bij een beroep op misbruik van machtspositie is dat niet nodig, omdat dan een beroep wordt gedaan op een algemeen verbod, onafhankelijk van enige overeenkomst. De relevante vraag is in een dergelijke situatie of bepaalde praktijken geoorloofd of ongeoorloofd zijn. De overeenkomst is in een dergelijke situatie 'slechts' nodig om te beoordelen of de betreffende praktijk daadwerkelijk bestaat. ${ }^{14}$

De zaak Volkswagen is strikt genomen geen mededingingskwestie, maar wij behandelen deze uitspraak desalniettemin vanwege de relevantie voor de mededingingspraktijk. Het betreft een schadevordering van een Oostenrijkse vereniging voor consumenteninformatie op basis van een gestelde waardevermindering van Volkswagenauto's als gevolg van de dieselemissiemanipulatie door Volkswagen.

De verwijzende rechter vroeg het Hof van Justitie of de Oostenrijkse rechter op basis van het Erfolgsort bevoegd was om te oordelen over deze vordering omdat het zuivere vermogensschade zou betreffen. Het Hof van Justitie oordeelt in glasheldere bewoordingen dat er geen sprake is van zuivere vermogensschade, en overigens wel sprake van directe schade. Het Hof van Justitie overweegt daartoe dat de schade ziet op een gebrek aan een materieel goed, namelijk de auto die geraakt is door de manipulatie. Aldus is er geen sprake van zuivere vermogensschade. Het feit dat de schade is uitgedrukt in geld doet daar niet aan af. ${ }^{15}$ Over de directheid van de schade oordeelt het Hof van Justitie dat deze pas intrad op het moment van de aankoop van de auto, als gevolg van de betaling van een hogere prijs dan de werkelijke waarde. ${ }^{16}$ Het Hof van Justitie sluit af met enkele overwegingen over de voorzienbaarheid. Het overweegt dat een autofabrikant die zijn onrechtmatig gemanipuleerde voertuigen in de handel brengt in een andere lidstaat mag verwachten voor de gerechten van die andere lidstaat opgeroepen te worden, aangezien voorzienbaar is dat de schade op de plaats van aankoop zal plaatsvinden. ${ }^{17}$

Voor de rechtbank Amsterdam lag een bevoegdheidsvraag voor in een stroomkabelkartelzaak. ${ }^{18}$ In deze zaken hadden eiseressen Electricity \& Water Authority of the Government of Bahrain c.s. een vordering ingesteld tegen buitenlandse gedaagden, voornamelijk geadresseerden van het stroomkabelkartelbesluit van de Europese Commissie, en daarnaast tegen bepaalde Nederlandse dochtermaatschappijen. Niet in geschil was dat de Nederlandse rechter bevoegd was jegens de Nederlandse dochtermaatschappijen op basis van (onder meer) artikel 4 EEX-Verordening. De vraag die voorlag, was of deze Nederlandse gedaagden konden dienen als ankergedaagden voor de buitenlandse gedaagden

\footnotetext{
14. Wikingerhof $\mathrm{GmbH} \&$ Co. $K G$ - Booking.com, r.o. 33-35.

15. Verein fur Konsumenteninformation - Volkswagen AG, r.o. 33-34.

16. Verein fur Konsumenteninformation - Volkswagen AG, r.o. 30.

17. Verein fur Konsumenteninformation - Volkswagen AG, r.o. 36-37.

18. Rb. Amsterdam 25 november 2011, ECLI:NL:RBAMS:2020:5882 (EWA Bahrein C.s./Prysmian Netherlands C.s.)
} 
vanwege een nauwe band tussen de vorderingen op basis van (onder meer) artikel 8 EEX-Verordening. Eiseressen stelden dat er sprake was van een nauwe band omdat de Nederlandse dochtermaatschappijen in de kartelperiode onderdeel waren van de ondernemingen van geadresseerden van het boetebesluit, en bovendien uitvoering hadden gegeven aan het (vrijwel) wereldwijde kartel (dat ook in Nederland actief was). De rechtbank Amsterdam wijst de bevoegdheid ten opzichte van de buitenlandse gedaagden af. $\mathrm{Zij}$ overweegt dat het feit dat de Nederlandse gedaagden onderdeel waren van de ondernemingen van geadresseerden onvoldoende was voor het aannemen van een nauwe band. ${ }^{19}$ Het Skanskaarrest van het Hof van Justitie inzake de aansprakelijkheid van de onderneming zou volgens de rechtbank specifiek zien op de situatie van herstructureringen, en mist daarom toepassing in de zaak. Ook was de eigen deelname van de Nederlandse gedaagden onvoldoende onderbouwd, aldus de rechtbank. ${ }^{20}$

Het oordeel van de rechtbank Amsterdam wijkt af van het vorig jaar besproken arrest van het gerechtshof Arnhem-Leeuwarden, waar het gerechtshof aansprakelijkheid van de onderneming aanneemt op basis van het Skanska-arrest. ${ }^{21}$ In het huidige jaar valt voor zover nodig meer opheldering te verwachten over deze vragen van bevoegdheid en aansprakelijkheid. De Audiencia Provincial van Barcelona heeft in de zaak Sumal namelijk prejudiciële vragen gesteld over aansprakelijkheid van de onderneming op basis van het ondernemingsbegrip. ${ }^{22}$

\section{Verjaring}

Vorig jaar hebben wij in deze kroniek het Cogeco-arrest van het Hof van Justitie besproken, inzake de strijdigheid van de Portugese verjaringsregels met het doeltreffendheidsbeginsel. Dit jaar is het arrest door de Nederlandse rechter toegepast.

Het gerechtshof Amsterdam beoordeelde in een natriumchloraatkartelzaak of de Finse, Zweedse en Spaanse verjaringsregels in overeenstemming waren met de overwegingen in Cogeco inzake het doeltreffendheidsbeginsel. Het gerechtshof interpreteert het Cogeco-arrest zodanig dat bij een follow-on vordering de benadeelde de definitieve beslissing van de mededingingsautoriteit (inclusief beroep) moet kunnen afwachten, en daarna nog voldoende tijd moet hebben om zijn schadevordering in te stellen. Een nationaal verjaringsregime dat hieraan in de weg staat, is in strijd met het doeltreffendheidsbeginsel. ${ }^{23}$ Het gerechtshof geeft hier-

19. EWA Bahrein C.s./Prysmian Netherlands C.S., r.o. 5.41

20. EWA Bahrein C.s./Prysmian Netherlands C.S., r.o. 5.24. Electricity \& Water Authority of the Government of Bahrain c.s. hebben hoger beroep ingesteld tegen het vonnis van de rechtbank.

21. Hof Arnhem-Leeuwarden 26 november 2019, ECLI:NL:GHARL: 2019:10165 (Alstom/TenneT). Zie ook buiten de kroniekperiode: Hof Amsterdam 16 februari 2021, ECLI:NL:GHAMS:2021:509 (MTB/ Heineken), waarin in het kader van een bevoegdheidsincident een nauwe band wordt aangenomen op basis van het ondernemingsbegrip.

22. Zaak C-882/19 (Sumal). Zie de conclusie van A-G Pitruzzella van 15 april 2021, ECLI:EU:C:2021:293.

23. Hof Amsterdam 4 februari 2020, ECLI:NL:GHAMS:2020:194 (CDC) Kemira), r.o. 3.5.4. mee ruim baan aan de volle werking van het Europese kartelverbod.

Op deze basis oordeelt het gerechtshof dat de Spaanse, Zweedse en Finse verjaringsregels in strijd zijn met het doeltreffendheidsbeginsel, dan wel dat de vorderingen niet verjaard zijn op basis van een Cogeco-conforme interpretatie van de nationale verjaringsregels. De reden is steeds dat afnemers de onherroepelijkheid van een kartelbesluit moeten kunnen afwachten voordat zij een schadevordering op basis van dat besluit instellen. Hierbij is niet slechts het besluit jegens de gedaagde relevant (die in dit geval niet in beroep was gegaan), maar ook de beroepen van de andere karteldeelnemers. Afnemers kunnen immers alle karteldeelnemers aanspreken tot vergoeding van de gehele door hen geleden schade ten gevolge van een enkele voortdurende overtreding van het mededingingsrecht. ${ }^{24}$

Het gerechtshof Den Bosch moest in een andere zaak ook een oordeel vellen over buitenlandse verjaringsregels, namelijk in een follow-on zaak gestart door Deutsche Bahn AG en gelieerde maatschappijen tegen verschillende deelnemers aan het spanstaalkartel. De vraag die voorlag, was of een vordering van Deutsche Bahn verjaard was onder Duits recht.

Het gerechtshof oordeelt dat de subjectieve verjaringstermijn van drie jaar was begonnen te lopen in het jaar volgend op de publicatie door de Europese Commissie van een samenvatting van het kartelbesluit. ${ }^{25}$ Een eerder persbericht en publicaties in de media bevatten onvoldoende informatie voor benadeelden om bekend te worden geacht met het bestaan van de schade (waarvoor ook de duur van de overtreding van iedere karteldeelnemer van belang is) en de aansprakelijke ondernemingen. ${ }^{26}$ De vorderingen waren aldus niet verjaard onder de subjectieve verjaringstermijn.

Bovendien: in afwijking van het eerdere oordeel van de rechtbank oordeelt het gerechtshof dat de objectieve verjaringstermijn van tien jaar ook niet is verlopen. $\mathrm{Na}$ het vonnis van de rechtbank had het Duitse Bundesgerichtshof in de zaak Grauzementkartel II geoordeeld dat een in 2005 ingevoerde provisie inzake schorsing van de objectieve verjaringstermijn hangende onderzoeken van mededingingsautoriteiten ook van toepassing is op mededingingsovertredingen voorafgaand aan 2005, althans voor vorderingen die nog niet verjaard waren voor dat jaar. ${ }^{27}$ Logischerwijs volgt het gerechtshof dit oordeel over Duits recht van het Bundesgerichtshof. ${ }^{28}$

Ten slotte voeren gedaagden nog aan tegen de vorderingen van Deutsche Bahn c.s. dat de verjaringstermijn niet was gestuit door het uitbrengen van de dagvaardingen, omdat de vordering in de dagvaarding onvoldoende zou zijn beschreven om te voldoen aan het Duitse individualiseringsvereiste. Het gerechtshof

24. $C D C /$ Kemira, r.o. 3.5.6

25. Onder Duits recht verjaren vorderingen per einde kalenderjaar.

26. Hof Den Bosch 28 januari 2020, ECLI:NL:GHSHE:2020:293 (Deutsche Bahn c.s./Nedri Spanstaal c.s.), r.o. 3.24-3.25.

27. Bundesgerichtshof 12 juni 2018, KZR 56/16, ECLI:DE:BGH:2018: 120618UKZR56.16.0 (Grauzementkartel II).

28. Grauzementkartel II, r.o. 3.33 
makkt korte metten met dit argument. Het was voor gedaagden, zoals ook bleek uit hun verweren, voldoende duidelijk uit de dagvaarding waar de vordering op zag. Van benadeelden hoeft bovendien niet verwacht te worden dat zij al bij dagvaarding alle concrete transactiegegevens indienen in relatie tot het kartel. Aangenomen mag worden dat de karteldeelnemers zelf weten wat zij in het kader van het kartel hebben gedaan. Voor concrete informatie naar aanleiding van de dagvaarding kunnen zij ook hun eigen administratie en medewerkers raadplegen. Een strengere eis zou ook mogelijk in strijd zijn met het Europese recht (naar auteurs aannemen verwijst het gerechtshof hier naar het doeltreffendheidsbeginsel). ${ }^{29}$

Auteurs merken op dat in de toekomst kartelschadezaken steeds vaker onder het temporele toepassingsbereik van de Kartelschaderichtlijn en de Nederlandse implementatiewet zullen vallen. ${ }^{30} \mathrm{Op}$ basis van de Nederlandse implementatiewet wordt de verjaringstermijn van rechtswege verlengd tot ten minste een jaar na het definitief worden van een inbreukbesluit. ${ }^{31}$ Met het Cogecoarrest van het Hof van Justitie en het arrest van het gerechtshof Amsterdam in de natriumchloraatzaak lijkt dit van beperkte relevantie geworden: ook in zaken waar de Kartelschaderichtlijn temporeel nog niet van toepassing is, worden de verjaringsregels door de Europese en Nederlandse rechter vanwege het doeltreffendheidsbeginsel zodanig toegepast dat deze al grotendeels in lijn zijn met de Kartelschaderichtlijn.

\section{Rechtsgeldigheid cessies}

In de Nederlandse follow-on procespraktijk wordt veelvuldig gebruikgemaakt van het zogenoemde cessiemodel. Dit cessiemodel houdt in dat een groep van benadeelden vorderingen cedeert aan een special purpose vehicle die de vorderingen vervolgens instelt in ruil voor een percentage van de opbrengst van de vordering. ${ }^{32}$ Vorig jaar bespraken wij een uitspraak waarin de rechtbank Rotterdam overwoog dat het cessiemodel een wezenlijke bijdrage kan leveren aan het vergemakkelijken van de afwikkeling van kartelschade en de effectiviteit van de handhaving van mededingingsregels. ${ }^{33}$ Samenvattend kan geconcludeerd worden dat de rechtsgeldigheid van het cessiemodel dit jaar in de hogere rechtspraak is bevestigd, en dat bovendien niet al te zware eisen worden gesteld aan de cessiedocumentatie.

Zo oordeelt het gerechtshof Amsterdam in de natriumchloraatzaak dat het cessiemodel, met een resultaatsafhankelijke beloning, gerechtvaardigd is in mededingingsschadezaken. Het gerechtshof overweegt daarbij dat het in dit soort zaken voor afnemers bezwaarlijk kan

29. Grauzementkartel II, r.o. 3.38-3.39

30. Richtlijn 2014/104/EU en de Implementatiewet privaatrechtelijke handhaving mededingingsrecht (in werking getreden op 9 februari 2017).

31. Art. 6:193t lid 2 Implementatiewet privaatrechtelijke handhaving mededingingsrecht.

32. Zie bijvoorbeeld T.M.C. Arons, 'Misbruik van bevoegdheid in collectieve acties: Drie afgebakende modellen van collectieve geschilbeslechting', MvO 2020, nr. 7

33. Rb. Rotterdam 23 oktober 2019, ECLI:NL:RBROT:2019:8230 (SECC) Kone c.s.), r.o. 9.31 zijn om op individuele basis te procederen. Omdat in de betreffende zaak ook daadwerkelijk overdracht van de vorderingen was beoogd, was het model bovendien niet in strijd met het fiduciaverbod van artikel 3:84 lid 3 BW. ${ }^{34}$ Tot een vergelijkbaar oordeel komt het gerechtshof ook in twee luchtvrachtzaken, met de toevoeging dat het model onder Nederlands recht tevens niet in strijd is met de openbare orde of goede zeden, ook niet als de cessionaris ten tijde van de cessie niet in staat is aan een eventuele proceskostenveroordeling te voldoen. ${ }^{35}$

In de twee luchtvrachtzaken laat het gerechtshof zich verder uit over de stelplicht en bewijslast bij cessies. Het gerechtshof overweegt dat een cessionaris onder Nederlands recht in beginsel aan zijn stelplicht heeft voldaan indien die de akte van cessie aan de schuldenaar heeft medegedeeld en een uittreksel van de akte en titel heeft overgelegd. Vervolgens is het aan de schuldenaar om te onderbouwen waarom de geldigheid van de cessie op redelijke gronden moet worden betwijfeld. Voor deze redelijke twijfel is het enkele feit dat die niet beschikt over alle informatie aan de hand waarvan de geldigheid van de overdracht kan worden vastgesteld, onvoldoende, omdat een schuldenaar een beperkte onderzoeksplicht heeft en in beginsel bevrijdend kan betalen aan een pseudocessionaris indien die op redelijke gronden kan aannemen dat cessie heeft plaatsgevonden. ${ }^{36}$

Tegen de achtergrond van deze verdeling van stelplicht en bewijslast worden de bezwaren van de gedaagde schuldenaren steeds afgewezen door het gerechtshof. Zo klaagden gedaagden in zowel de bovenbeschreven natriumchloraatzaak als de twee luchtvrachtzaken dat onvoldoende duidelijk was welke vorderingen bij wijze van cessie door benadeelden waren overgedragen aan de claimentiteit. In alle zaken was aan dit bepaalbaarheidsvereiste voldaan volgens het gerechtshof, omdat de cessieovereenkomsten voldoende gegevens bevatten om naderhand vast te stellen welke vorderingen waren geleverd. ${ }^{37}$ Een omschrijving dat alle vorderingen met betrekking tot kartelschade in een bepaalde periode waren overgedragen was voldoende specifiek. Voor de karteldeelnemers moet bovendien bekend zijn geweest wat hun rol was in het kartel, aldus het gerechtshof in de natriumchloraatzaak. ${ }^{38}$

Ook verweren van gedaagden in de luchtvrachtzaken met betrekking tot de beschikkingsbevoegdheid, de vertegenwoordigingsbevoegdheid en echtheid van handtekeningen in cessiedocumentatie worden met een enkele
34. CDC/Kemira, r.o. 3.14.3. Zie ook de luchtvrachtzaken Hof Amsterdam 10 maart 2020, ECLI:NL:GHAMS:2020:714 (Equilib/KLM C.s.), r.o. 2.2 en Hof Amsterdam 10 maart 2020, ECLI:NL:GHAMS:2020:713 (SCC I en SCC II/KLM C.S.), r.o. 4.8.1.

35. SCC I en SCC II/KLM C.S., r.o. 4.14.1

36. Equilib/KLM C.S., r.o. 4.10.3-4.10.5 en SCC I en SCC II/KLM C.S., r.o. 4.5.3-4.5.5

37. CDC/Kemira, r.o. 3.12.4-3.12.5, Equilib/KLM C.S., r.o. 4.14.1 en SCC I en SCC II/KLM C.S., r.o. 4.9.2-4.9.3 en 4.9.7.

38. $C D C /$ Kemira, r.o. 3.12 .4 
uitzondering steeds afgewezen. ${ }^{39}$ Tot slot overweegt het gerechtshof in de luchtvrachtzaken nog dat indien Nederlands recht van toepassing is op de vorderingen, de cessionarissen een beroep kunnen doen op het vermoeden dat zij rechthebbende zijn op de vorderingen die zij door middel van cessie hebben verkregen, omdat zij al geruime tijd ongestoord in bezit waren van de vorderingen. ${ }^{40}$

\section{Stand-alone zaken}

\section{Stelplicht en bewijslast}

- Verzmaarde motiveringsplicht gedaagde

Stelplicht en bewijslast zijn een terugkerend thema in deze kroniek. In 2020 lijkt er een trendbreuk op dit onderwerp te zijn opgetreden. In vorige kronieken verzuchtten auteurs nog dat het $I A T A$-arrest ${ }^{41}$ voor veel eisers een (te) moeilijk te nemen horde was. ${ }^{42}$ Daarentegen zijn feitenrechters in 2020 eisende partijen meermaals te hulp geschoten.

Dit gebeurde allereerst in een procedure tussen de vereniging Associated Business Music Distributors en enkele van haar leden (ABMD) en Buma/Stemra. ${ }^{43}$ $\mathrm{AMDB}$ is een belangenorganisatie van bedrijven die afspeelapparatuur, software en muziekbestanden leveren aan zakelijke gebruikers van achtergrondmuziek, zoals horecagelegenheden, winkels en fitnesscentra. In

Nederland is Buma/Stemra de enige partij die namens makers van muziekwerken bedrijfsmatig mag bemiddelen bij het aangaan of uitvoeren van overeenkomsten voor het gebruik van muziekwerken in het openbaar of de uitzending daarvan in radio- of televisieprogramma's. Om muziekbestanden aan hun afnemers te kunnen leveren, hebben AMDB-leden dus een licentie nodig van Buma/Stemra. Hiervoor betalen zij significant hogere tarieven dan streamingplatforms als Spotify, terwijl veel zakelijke eindgebruikers streamingdiensten gebruiken om achtergrondmuziek in hun etablissement te spelen. Overigens staan de gebruikersvoorwaarden van het desbetreffende platform dergelijk commercieel gebruik doorgaans niet toe.

Volgens AMDB makt Buma/Stemra misbruik van haar economische machtspositie door discriminatoire tarieven te hanteren en niet handhavend op te treden

39. Equilib/KLM C.s., r.o. 4.17.1-4.17.2, 14.18.1, 4.22.1-4.22.2 en SCC I en SCC II/KLM C.S., r.o. 4.12.1-4.13.3. Met betrekking tot twee benadeelden uit de achterban van Equilib hadden gedaagden KLM c.s. voldoende onderbouwd dat er redelijke gronden waren voor twijfel aan de rechtsgeldigheid van de cessies omdat vast was komen te staan dat de personen die de cessiedocumentatie hadden getekend hun vertegenwoordigingsbevoegdheid hadden overschreden.

40. Equilib/KLM C.S., r.o. 4.25.2-4.25.4 en SCC I en SCC II/KLM C.s., r.o. 4.18.4.

41. HR 21 december 2012, ECLI:NL:HR:2012:BX0345 (ANVR/IATA),

42. S. Tuinenga \& M. Meijssen, 'Kroniek civiele rechtspraak 2019', M\&M 2020/2, p. 49; en M. Bredenoord-Spoek \& S. de Jong, 'Kroniek civiele rechtspraak mededingingsrecht 2018', M\&M 2019/1, p. 4.

43. Hof Amsterdam 15 september 2020, ECLI:NL:GHAMS:2020:2583 (ABMD C.s./Buma/Stemra). tegen zakelijk gebruik door abonnees van streamingdiensten. In eerste aanleg had de rechtbank Amsterdam AMDB op dit punt deels in het gelijk gesteld. $\mathrm{Zij}$ had Buma/Stemra verboden om een hogere vergoeding aan de AMDB-leden in rekening te brengen dan zij bij streamingdiensten deed, en haar veroordeeld om een bij staat op te maken schadevergoeding te betalen.

In hoger beroep moet het gerechtshof Amsterdam onder meer oordelen over de vraag of Buma/Stemra beschikt over een machtspositie en of zij daarvan misbruik maakt. Het gerechtshof oordeelt dat de stelplicht en bewijslast rust op AMDB. Het gerechtshof komt AMDB echter tegemoet. Volgens het gerechtshof rust er een verzwaarde onderbouwingsplicht op Buma/Stemra, omdat zij beschikt over feitelijke gegevens die aanknopingspunten bevatten voor de bewijslevering door AMDB, terwijl AMDB hier niet over kan beschikken. ${ }^{44}$ Dit geldt voor zowel feiten die zien op de machtspositie van Buma/ Stemra (zoals haar positie op de domnstream markt en de samenwerking tussen Buma en Stemra) als feiten die gaan over het misbruik (zoals de mate waarin Buma/ Stemra handhavend optreedt). Het gerechtshof oordeelt dat Buma/Stemra hierover onvoldoende informatie ingebracht heeft, en spreekt het voornemen uit om Buma/Stemra te veroordelen om deze gegevens in het geding te brengen. Voordat het een dergelijke bewijsopdracht zal geven, gelast het een comparitie om te bespreken hoe invulling gegeven moet worden aan de verzwaarde onderbouwingsplicht van Buma/Stemra. Daarbij spreekt het gerechtshof de waarschuwing uit dat als Buma/Stemra hier niet aan voldoet, het de stellingen van AMDB als onvoldoende betwist en daarmee als vaststaand zal aannemen.

De tweede zaak waarin een verzwaarde motiveringsplicht werd aangenomen, betreft een geschil tussen netbeheerder Enexis en een ongenoemde gedaagde. ${ }^{45}$ Enexis had deze partij gedagvaard, omdat die Enexis' rekening voor het verwijderen van twee oude aansluitingen en het realiseren van een nieuwe niet had betaald. De gedaagde partij beriep zich er, kort gezegd, op dat de prijzen van Enexis excessief waren.

Ook in deze zaak oordeelde de rechtbank Gelderland dat de stelplicht en bewijslast dat Enexis misbruik maakte van haar machtspositie in beginsel rust op de partij die zich op deze stelling beroept (in dit geval: de gedaagde). ${ }^{46}$ Hoewel de rechtbank geen aanleiding ziet om de bewijslast om te keren, is zij wel van mening dat er een verzwaarde motiveringsplicht op Enexis rust. De rechtbank stelt Enexis daarom in staat om uit te leggen welke werkzaamheden zij heeft verricht, hoe zij de kosten daarvan heeft berekend en waarom de geoffreerde prijs in redelijke verhouding staat tot de economische waarde van de werkzaamheden.

\footnotetext{
44. ABMD c.s./Buma/Stemra, r.o. 3.2.3 en 3.2.4.

45. Rb. Gelderland 2 december 2020, ECLI:NL:RBGEL:2020:6280 (Enexis/ $X)$.

46. Enexis/X, r.o. 2.6-2.7
} 
- Afmijzing vordering megens onvoldoende onderbouming

Het bovenstaande betekent overigens niet dat er in 2020 geen vorderingen werden afgewezen omdat stellingen onvoldoende gemotiveerd waren. In deze paragraaf bespreken wij er drie. ${ }^{47} \mathrm{Wij}$ tekenen hierbij aan dat geen van deze zaken bodemprocedures betrof, en het reguliere toetsingskader dus niet van toepassing was. Twee zaken betreffen een kort geding en de derde een verzoek om een voorlopig getuigenverhoor.

De eerste zaak betreft een kortgedingprocedure tussen geneesmiddelendistributeur Eureco-Pharma en zorgverzekeraar Zilveren Kruis over de (gestelde) verhindering van paralleldistributie van het geneesmiddel Imbruvica. ${ }^{48}$ Eureco-Pharma was lange tijd de belangrijkste leverancier van Imbruvica voor ziekenhuizen. EurecoPharma kocht Imbruvica in andere EU-lidstaten in voor een lagere prijs dan waarvoor dit medicijn in Nederland beschikbaar was, en kon daardoor ook voor een lagere prijs aan ziekenhuizen leveren dan als de ziekenhuizen direct bij het Nederlandse verkoopkanaal van producent Janssen-Cilag inkochten. De vergoeding die ziekenhuizen ontvingen van verzekeraars voor de inkoop van het medicijn was ook hoger dan de inkoopprijs bij EurecoPharma. Zilveren Kruis probeerde deze situatie te beëindigen. Samen met andere zorgverzekeraars bedong zij bij producent Janssen-Cilag volumekortingen voor Imbruvica. Ook wijzigde Zilveren Kruis de vergoedingen voor Imbruvica: deze werden met 49\% gekort als ziekenhuizen het medicijn bij andere partijen dan Janssen-Cilag inkochten.

Daarop startte Eureco-Pharma een kort geding. De voorzieningenrechter van de rechtbank Midden-Nederland acht onvoldoende onderbouwd dat de verzekeraars onderling afspraken hadden gemaakt over de vergoedingen aan Eureco-Pharma. De rechtbank overweegt dat de verzekeraars weliswaar gezamenlijk afspraken hadden gemaakt met Jansen-Cilag over de vergoedingen die zij betaalden voor de bij Janssen-Cilag ingekochte Imbruvica, maar dat niet was aangetoond dat ook afspraken waren gemaakt over vergoedingen voor inkoop bij andere leveranciers (zoals Eureco-Pharma). Dat het inkoopverband ook los van afspraken over vergoedingen voor Eureco-Pharma in strijd is met de mededinging acht de rechtbank ook onvoldoende onderbouwd. Volgens de voorzieningenrechter had EurecoPharma 'niet duidelijk gemaakt welke belemmering van welke mededinging volgens haar schuilt in het inkoopverband en hoe zij daardoor in haar belangen wordt geraakt, terwijl het op haar weg ligt om dat duidelijk te maken'. ${ }^{49}$ Een onderling afgestemde feitelijke gedraging tussen de verzekeraars en de ziekenhuizen vanwege aan-

47. Zie ook: Rb. Rotterdam 26 februari 2020, ECLI:RBROT:2020:1604, Hof Amsterdam 14 april 2020, ECLI:NL:GHAMS:2020:1309 (Claim Participants/ABN AMRO); Hof Den Haag 15 december 2020, ECLI:NL:GHDHA:2020:2473

48. Rb. Midden-Nederland 8 juni 2020, ECLI:NL:RBMNE:2020:2117 (Eureco-Pharma/Zilveren Kruis).

49. Eureco-Pharma/Zilveren Kruis, r.o. 3.10. vaarding door de ziekenhuizen van het nieuwe vergoedingsbeleid acht de rechtbank ook niet aangetoond..$^{50}$

Een tweede kortgedingprocedure die stukliep op de onderbouwing is die tussen De Vos Diensten Enschede (De Vos) en PostNL. ${ }^{51}$ Onderwerp van geschil was dat Sandd in de aanloop naar de fusie met PostNL de postbezorgingsovereenkomsten met De Vos had beëindigd. Volgens De Vos was er geen regelmatige opzeggingsgrond, omdat de rechtbank Rotterdam het vergunningsbesluit ex artikel $47 \mathrm{Mw}$ voor de concentratie tussen PostNL en Sandd had vernietigd. ${ }^{52}$ Volgens De Vos moet er daarom van uitgegaan worden dat, zonder goedkeuring voor de fusie, Sandd de bestaande relatie zal voortzetten onder gelijkblijvende voorwaarden. Daarnaast was De Vos van mening dat de opzegging van de Sandd-overeenkomsten in strijd was met artikel 102 Verdrag betreffende de werking van de Europese Unie (VWEU) en artikel 24 Mededingingswet (Mw), omdat deze kwalificeert als een (constructieve) leveringsweigering en als margin squeeze.

De voorzieningenrechter van de rechtbank Den Haag zag echter geen juridische basis om de vordering toe te wijzen. ${ }^{53}$ Volgens de voorzieningenrechter hoeft er niet van uitgegaan te worden dat de fusie tussen PostNL en Sandd moet worden teruggedraaid. Daarbij merkt de voorzieningenrechter op dat de fusie vooralsnog in stand is gebleven en de postnetwerken feitelijk zijn samengevoegd. Volgens de voorzieningenrechter kan in kort geding bovendien niet worden vastgesteld of PostNL misbruik maakt van haar economische machtspositie. Volgens de voorzieningenrechter had De Vos nagelaten om een deugdelijk onderbouwde stellingname te formuleren met een inzichtelijke berekening van de financiële consequenties van de beëindiging van de overeenkomsten. Het komt de voorzieningenrechter niet onredelijk voor dat PostNL de tarieven en voorwaarden hanteerde die de staatssecretaris had vastgesteld in de overgangsregeling voor vervoerders die gebruikmaakten van het Sandd-netwerk.

De laatste te bespreken procedure waarbij onvoldoende was gesteld betreft een verzoek om een voorlopig getuigenverhoor. ${ }^{54}$ Dit verzoek werd gedaan door Hudson's Bay's Company ULC (HBC). Zij meende dat de verhuurders van winkelpanden onderling voorwaarden hadden afgestemd in het kader van de verhuur aan haar (inmiddels failliete) Nederlandse dochtervennootschap HBC Netherlands B.V. (HBC NL).

De rechter kan een voorlopig getuigenverhoor afwijzen bij misbruik van procesrecht, als de goede procesorde of zwaarwegende belangen van derden zich tegen toewijzing verzetten en bij onvoldoende belang. Volgens de

50. Eureco-Pharma/Zilveren Kruis, r.o. 3.12.

51. Rb. Den Haag, ECLI:NL:RBDHA:2020:13586 (De Vos Diensten Enschede/PostNL).

52. Rb. Rotterdam 11 juni 2020, ECLI:NL:RBROT:2020:5122 (X/staats secretaris $E Z K)$. Zie voor een nadere bespreking van deze uitspraak: W. Knibbeler \& P. Kreijger, 'De dag die je wist dat zou komen - kanttekeningen bij PostNL/Sandd', M\&M 2020/3, p. 105-117.

53. De Vos Diensten Enschede/PostNL, r.o. 4.10 e.v.

54. Rb. Amsterdam 24 september 2020, ECLI:NL:RBAMS:2020:4615 (HBC) ASR Dutch Prime Retail Custodian C.s.) 
rechtbank Amsterdam waren al deze afwijzingsgronden in deze zaak van toepassing. ${ }^{55}$ De rechtbank overweegt daartoe dat het verzoek van HBC van een magere, deels inconsistente onderbouwing was voorzien, een lichtvaardig karakter had en onsamenhangend was. ${ }^{56}$

\section{Reikwijdte mededingingsrecht}

Tijdens dit kroniekjaar viel het op dat rechters vaker dan gebruikelijk een oordeel moesten vellen over de vraag of een overeenkomst binnen het bereik van het mededingingsrecht viel. Het ging hier met name om de vraag of het mededingingsrecht van toepassing is op afspraken die een sociale doelstelling moesten dienen. Wij bespreken er drie. ${ }^{57}$

In de vorige kroniek gingen wij al in op de zaak tussen Zelfstandigen Bouw en de Staat en Bpf Schilders. Zelfstandigen Bouw wilde af van de verplichte pensioenopbouw voor zzp-schilders bij Bpf Schilders. De Staat had dit verplicht gesteld nadat de sociale partners hierom verzocht hadden. De rechtbank Den Haag had in eerste aanleg geoordeeld dat de sociale partners weliswaar ondernemingen waren, maar dat hun gezamenlijke aanvraag om zzp-schilders verplicht pensioen te laten opbouwen geen mededingingsbeperkende strekking of gevolg had. ${ }^{58}$

Ook in hoger beroep oordeelde het gerechtshof Den Haag dat zzp-schilders als ondernemingen (en dus niet als 'schijnzelfstandigen') aangemerkt moeten worden. ${ }^{59}$ Dit is van belang, omdat zzp-schilders zich hadden aangesloten bij zowel de werkgevers- als de werknemersorganisaties die het verplichtstellingsverzoek hadden gedaan. Hierdoor was de overeenkomst die aan het verplichtstellingsverzoek van de sociale partners ten grondslag lag, niet zuiver het resultaat van collectieve onderhandelingen tussen werkgevers- en werknemersorganisaties. Onder verwijzing naar $F N V$ Kiem $^{60}$ oordeelt het gerechtshof dat er daarom sprake is van een overeenkomst tussen ondernemingen. Om dezelfde redenen acht het gerechtshof artikel 16 onder b Mw, dat bepaalt dat het kartelverbod niet geldt voor pensioenafspraken tussen werkgevers- en werknemersorganisaties, niet van toepassing. ${ }^{61}$

De Staat en Bpf Schilders hadden, onder verwijzing naar het Pavlov-arrest van het Hof van Justitie, ${ }^{62}$ nog betoogd dat het verplichtstellingsbesluit buiten de werkingssfeer van artikel 101 lid 1 VWEU jo. artikel 4 lid 3 Verdrag betreffende de Europese Unie (VEU) viel, omdat de Staat hiermee een regelgevende bevoegdheid op sociaal gebied uitoefent. Het gerechtshof oordeelt dat

55. HBC/ASR Dutch Prime Retail Custodian C.s., r.o. 4.10

56. HBC/ASR Dutch Prime Retail Custodian C.s., r.o. 4.10.

57. Zie ook Hof Den Bosch 7 januari 2020, ECLI:NL:GHSHE:2020:17 (X/CZ Groep).

58. Rb. Den Haag 30 januari 2019, ECLI:NL:RBDHA:2019:702 (Zelfstandigen Bouw/Staat), r.o. 5.15-5.18 en 5.25.

59. Hof Den Haag 22 december 2020, ECLI:NL:GHDHA:2020:2384 (Zelfstandigen Bouw/Bpf Schilders), r.o. 5.11.

60. HvJ EU 4 december 2014, zaak C-413/14, ECLI:EU:C:2014:2411 (FNV Kiem).

61. Zelfstandigen Bouw/Bpf Schilders, r.o. 5.14.

62. HvJ EG 12 september 2000, gevoegde zaken C-180/98 t/m C-184/98, ECLI:EU:C:2000:428 (Pavlov). dit standpunt op een te beperkte lezing van Pavlov is gebaseerd. ${ }^{63}$ Volgens het gerechtshof oordeelt het Hof van Justitie in Pavlov juist dat ook wanneer de Staat zijn regelgevende bevoegdheid op sociaal gebied uitoefent wanneer hij deelname aan een pensioenfonds verplicht stelt, hij artikel 101 lid 1 VWEU jo. artikel 4 lid 3 VEU kan schenden als door dat besluit de mededinging merkbaar beperkt wordt.

Het gerechtshof oordeelt overigens dat dit niet het geval is. Volgens het gerechtshof heeft de overeenkomst die ten grondslag ligt aan het verplichtstellingsbesluit geen mededingingsbeperkende strekking of (merkbare) mededingingsbeperkende gevolgen. ${ }^{64}$ Nog vermeldenswaardig is hoe het gerechtshof kijkt naar de schadetheorie dat de verplichte pensioendeelname leidt tot hogere gezamenlijke kosten en daarmee tot een hoger prijsniveau. ${ }^{65}$ Zelfstandigen Bouw had in dit kader aangevoerd dat zowel de premies als de uitvoeringskosten als gemeenschappelijke kosten in aanmerking genomen moeten worden. Daarbij wees Zelfstandigen Bouw erop dat de opgebouwde pensioenrechten niet een-op-een gekoppeld kunnen worden aan de betaalde premies, en dat de waarde van de bij Bpf Schilders opgebouwde pensioenrechten in de afgelopen jaren waren gedaald. Het gerechtshof oordeelt echter, wederom onder verwijzing naar Pavlov, dat alleen de uitvoeringskosten moeten worden meegenomen. Deze acht het zo gering dat deze niet kunnen leiden tot een mededingingsbeperkende commonality of costs.

Eveneens interessant is dat het gerechtshof artikel 102 jo. $106 \mathrm{VWEU}$ ambtshalve toepast. ${ }^{66}$ De vraag in hoeverre een Nederlandse hogerberoepsrechter buiten de grieven om ambtshalve het mededingingsrecht moet toepassen is in de jurisprudentie nog niet volledig uitgekristalliseerd. ${ }^{67}$ Zo oordeelde het gerechtshof Arnhem-Leeuwarden in 2019 nog dat artikel 101 VWEU niet ambtshalve buiten de grieven om toegepast hoeft te worden. ${ }^{68}$ Het gerechtshof Den Haag lijkt van oordeel te zijn dat deze verplichting wel bestaat. Het gerechtshof concludeert overigens uiteindelijk dat het geen misbruik van machtspositie kan vaststellen, omdat Zelfstandigen Bouw hiertoe onvoldoende heeft aangevoerd. Men kan zich afvragen wat ambtshalve toepassing dan toevoegt buiten evidente schendingen. Bij complexere mededingingszaken zal het zo zijn dat een partij die zich niet op het mededingingsrecht beroept, ook niet voldoende

63. Zelfstandigen Bouw/Bpf Schilders, r.o. 5.13

64. Zelfstandigen Bouw/Bpf Schilders, r.o. 5.16 e.v

65. Zelfstandigen Bouw/Bpf Schilders, r.o. 5.22 e.v

66. Zelfstandigen Bouw/Bpf Schilders, r.o. 5.31 e.v.

67. Het gerechtshof Amsterdam stelde hier jaren geleden prejudiciële vragen over in de zaak UPC Nederland/Gemeente Hilversum, maar het Hof van Justitie beantwoordde deze vragen niet vanwege gebrek aan belang. Zie Hof Amsterdam 4 oktober 2011, ECLI:NL:GHAMS: 2011:BT6548 (UPC Nederland/Gemeente Hilversum) en HvJ EU 7 november 2013, zaak C-518/11, ECLI:EU:C:2013:709 (UPC Nederland/Gemeente Hilversum); en S. Tuinenga \& J.S. Kortmann, 'Kroniek civiele rechtspraak mededingingsrecht 2011', M\&M 2012/2, p. 55-65.

68. Hof Arnhem-Leeuwarden 26 maart 2019, ECLI:NL:GHARL:2019:2670 (Deddens C.s./Avebe). Zie voor een bespreking van dit arrest Tuinenga \& Meijssen 2020, p. 50 . 
feiten aandraagt om een ambtshalve mededingingsrechtelijke analyse door de rechter mogelijk te maken.

Terwijl Zelfstandigen Bouw bot ving bij het gerechtshof Den Haag, achtte de rechtbank Rotterdam een andere afspraak tussen sociale partners wel nietig. ${ }^{69}$ Het betrof de zogenoemde Non-Seafarers Work Clause. Dit is een standaardclausule die werkgevers die zijn aangesloten bij de International Maritime Employers' Council (IMEC) hanteren in arbeidsovereenkomsten met scheepsbemanning. Deze bepaling houdt in dat zeevaarders geen sjorwerkzaamheden mogen verrichten in havens waar aan de International Transport Workers' Federation (ITF) gelieerde sjorbedrijven sjorwerkzaamheden aanbieden. ITF is een internationale vakbondsfederatie van lokale vakbonden voor zeevarenden en havenwerkers. $\mathrm{Zij}$ onderhandelt iedere twee jaar met de Joint Negotiating Group, een internationaal collectief van maritieme werkgeversorganisaties waartoe ook IMEC behoort, over de beloning en arbeidsvoorwaarden van zeevarenden. Reders zijn eveneens aan deze afspraken gebonden door middel van met de vakbonden gesloten special agreements.

ITF had vastgesteld dat Marlow, een scheepsmanagementconcern dat lid is van IMEC, toch sjorwerkzaamheden door zeevarenden - en niet door havenmedewerkers - liet verrichten. Daarop startte zij samen met drie lokale vakbonden, waaronder FNV Havens, een kort geding tegen twee Marlow-concernvennootschappen en de eigenaar van een door Marlow bemand schip (de 'Reder'). In deze procedure vorderden ITF c.s. nakoming van de Non-Seafarers Work Clause. Aan de zijde van Marlow en de Reder voegden zich een vijftal bevrachters (de 'Charterers'). De Charterers hadden in mei 2020 bij de Europese Commissie een klacht tegen ITF en FNV Havens ingediend wegens schending van het mededingingsrecht.

De voorzieningenrechter oordeelt dat het 'niet onaannemelijk' is dat de Non-Seafarers Work Clause de mededinging beperkt tussen scheepsexploitanten. ${ }^{70} \mathrm{Zij}$ kunnen onderling niet meer concurreren op het verrichten van sjorwerkzaamheden. Ook wordt de concurrentie tussen bevrachters en sjorbedrijven verhinderd, omdat sjorwerkzaamheden worden voorbehouden aan aan ITF-gelieerde sjorbedrijven. Dit leidt ertoe dat in bepaalde havens, waaronder de haven van Rotterdam, sjorwerkzaamheden zijn voorbehouden aan één monopolist.

ITF c.s. hadden nog betoogd dat de Non-Seafarers Work Clause is opgenomen in een cao, en deze volgens het Albany-arrest niet binnen het bereik van het mededingingsrecht valt. ${ }^{71}$ De voorzieningenrechter verwerpt dit verweer. Naar diens mening rechtvaardigen de aard en doelstelling van de Non-Seafarers Work Clause niet dat deze buiten de werkingssfeer van het kartelverbod valt. ${ }^{72}$ Het is onvoldoende duidelijk of de Non-Seafarers Work Clause bijdraagt aan de verbetering van de arbeidsvoorwaarden, omdat zeevarenden werkgelegenheid en loon wordt ontzegd. Bovendien is het niet duidelijk dat hun veiligheid verbetert omdat zij geen sjorwerkzaamheden meer verrichten. De voorzieningenrechter wijst daarom de vorderingen van ITF c.s. af.

Een derde uitspraak waarin sociale overwegingen een rol spelen, is die van het gerechtshof Den Haag in een procedure tussen een aantal schoonmaakbedrijven en de Staat. ${ }^{73}$ Deze schoonmaakbedrijven werden door de Staat ingehuurd om overheidsgebouwen schoon te maken. Op een gegeven moment koos de Staat er echter voor om schoonmaakwerkzaamheden in te besteden, omdat zij medewerkers in lage loonschalen zelf in loondienst wilde nemen. De contracten met de schoonmaakbedrijven zouden in de loop van de jaren uitgefaseerd worden.

De schoonmaakbedrijven stapten vervolgens naar de rechter om een verklaring voor recht te vorderen dat de inbesteding onrechtmatig was. Hoewel de eiseressen hun vorderingen baseerden op een schending van artikel 107 VWEU, hebben wij er toch voor gekozen om dit arrest te bespreken vanwege de interpretatie die het gerechtshof aan het ondernemingsbegrip geeft. Het gerechtshof oordeelt dat hetzelfde ondernemingsbegrip van toepassing is op basis van artikel $101 \mathrm{VWEU}$ als 107 VWEU. Het overweegt dat 'wanneer sprake is van een onderneming van artikel $101 \mathrm{VWEU}$ is de Staat wel gebonden aan het mededingingsrecht en dus ook aan artikel 107 VWEU' ${ }^{74}$

Volgens het gerechtshof is de Rijksschoonmaakorganisatie (RSO) voor wat betreft de aan de orde zijnde schoonmaakdiensten geen onderneming in de zin van artikel 101 en 107 VWEU. ${ }^{75}$ Daarbij neemt het gerechtshof in overweging dat de RSO onderdeel uitmaakt van de rechtspersoon Staat. Zij verricht alleen schoonmaakwerkzaamheden in rijksoverheidsgebouwen en biedt haar diensten niet op de markt aan derden aan. Ook sluit de RSO geen overeenkomsten met rijksoverheidsinstanties waarbij zij schoonmaakt. Zij kan bovendien niet zelfstandig besluiten welke schoonmaakwerkzaamheden zij wel, en welke zij niet uitvoert. Omdat de RSO geen onderneming is voor deze schoonmaakdiensten, concludeert het gerechtshof dat zij ook geen ontvanger kan zijn van (illegale) staatssteun. ${ }^{76}$ Het gerechtshof wijst de vorderingen van de schoonmaakbedrijven op deze grond af.

Misbruik machtspositie

Misbruik van machtspositie door dominante platforms is momenteel een hot topic onder mededingingsrechtjuristen en -economen. Er is dan ook lang uitgekeken naar
69. Rb. Rotterdam 27 augustus 2020, ECLI:NL:RBROT:2020:7502 (International Transport Workers' Federation C.s./Marlow Navigation Netherlands C.s.).

70. International Transport Workers' Federation c.s./Marlow Navigation Netherlands C.S., r.o. 4.22.

71. HvJ EG 21 september 1999, zaak C-67/96, ECLI:EU:C:1999:430 (Albany).
72. International Transport Workers' Federation c.s./Marlow Navigation Netherlands C.S., r.o. 4.26.

73. Hof Den Haag 12 mei 2020, ECLI:NL:GHDHA:2020:898 (CSU C.S./ Staat).

74. CSU c.s./Staat, r.o. 5.1.

75. CSU C.s./Staat, r.o. 5.2-5.10.

76. CSU C.s./Staat, r.o. 5.11 
het arrest van het gerechtshof Amsterdam in het langslepende conflict tussen de makelaarsvereniging VBO makelaars (VBO) enerzijds en Funda, NVM en Brainbay (Funda c.s.) anderzijds. ${ }^{77}$ In deze zaak verwijt VBO Funda c.s. misbruik te maken van haar machtspositie op de markt voor huizensites in Nederland door de woningmakelaars van de aan haar gelieerde makelaarsvereniging $\mathrm{NVM}$ te bevoordelen ten opzichte van de makelaars van VBO.

Het gerechtshof oordeelt dat misbruik van machtspositie niet is aangetoond ${ }^{78}$ en bevestigt daarmee het vonnis van de rechtbank Amsterdam. ${ }^{79}$ Het gerechtshof neemt voor zijn analyse een machtspositie van Funda aan, en gebruikt als uitgangspunt voor zijn beoordeling het $M E O$-arrest van het Hof van Justitie. ${ }^{80} \mathrm{Uit}$ dit arrest volgt dat beoordeeld moet worden of de aan Funda c.s. verweten gedragingen potentieel (concurrentie)nadeel aan de VBO-makelaars berokkenen, waarbij een dergelijk nadeel moet worden gebaseerd op alle omstandigheden van het geval. Van belang is volgens het gerechtshof dat VBO niet concurreert op de markt van huizensites waarop Funda actief is, maar op de verschillende stroomafwaartse lokale markten voor woningmakelaardij. ${ }^{81}$

Het gerechtshof overweegt dat het nadeel voor VBOmakelaars niet in abstracto op basis van economische theorie behandeld kan worden, maar dat op VBO de stelplicht rustte om in concreto nadeel voor haar makelaars op de lokale markten voor woningmakelaardij aan te tonen. ${ }^{82}$ Het gerechtshof oordeelt dat VBO onvoldoende heeft gesteld met betrekking tot het nadeel dat de verweten gedragingen aan haar makelaars zou berokkenen.

Wij zullen twee van de verweten gedragingen uit het arrest nader uitlichten. De eerste verweten gedraging betrof dat de VBO-makelaars tot november 2015 een lagere ranking kregen op de Fundawebsite dan de NVM-makelaars. Dit betekent dat op de website van Funda eerst het aanbod van NVM-makelaars werd getoond, en dan pas het aanbod van andere makelaars zoals VBO. Volgens VBO berokkent het lager plaatsen van zoekresultaten naar zijn aard nadeel aan VBO-makelaars. VBO verwees in dit kader onder meer naar een

77. In 2019 waren reeds enkele procedurele aspecten beslecht, waaronder het in hoger beroep ook instellen van de vorderingen jegens gevoegde partijen NVM en Brainbay. Zie daarover de kroniek van vorig jaar. Brainbay is een door NVM opgerichte afsplitsing van NVM die is opgericht voor het beheren van portalen voor NVM.

78. Hof Amsterdam 26 mei 2020, ECLI:NL:GHAMS:2020:1337 (VBO c.s./ Funda C.S.).

79. Rb. Amsterdam 21 maart 2018, ECLI:NL:RBAMS:2018:1654 (VBO c.s./ Funda C.S.). Het vonnis is in dit tijdschrift besproken in een lezenswaardige annotatie van J. Mulder, 'Wat is een nadeel voor de mededinging en wie bepaalt dat? Over de rol van deskundigen en de bewijsstandaard in het kader van discriminatie door een dominant platform', M\&M 2018/4, p. 170. De observaties van Mulder over het vonnis van de rechtbank zijn grotendeels ook van toepassing op het arrest van het gerechtshof.

80. HvJ EU 19 april 2018, zaak C-413/14, ECLI:EU:C:2018:279 (MEO).

81. Hof Amsterdam 26 mei 2020, ECLI:NL:GHAMS:2020:1337 (VBO C.s./ Funda c.s.), r.o. 3.8.

82. Hof Amsterdam, VBO c.s./Funda c.s., r.o. 3.11. door haar ingediend economisch rapport, het Google Search Shopping-besluit van de Europese Commissie en een marktscan van de Nederlandse mededingingsautoriteit uit 2012 waarin was vermeld dat niet-NVMmakelaars klanten mislopen door een lagere positie in de zoekresultaten. Voor het gerechtshof leggen deze argumenten onvoldoende gewicht in de schaal. Het gerechtshof overweegt dat de ranking slechts van ondergeschikt belang is bij een product als een woning, omdat woningzoekenden vanwege het financiële belang van de aankoop over het algemeen langdurig, intensief en gericht zullen zoeken op de Fundawebsite. ${ }^{83}$ Ter onderbouwing verwijst het hierbij naar tegenrapporten van Funda c.s. en een in eerste instantie opgesteld deskundigenbericht waarin de deskundigen (ongevraagd) ${ }^{84}$ hadden geconcludeerd dat er geen eenduidige aanwijzingen waren voor nadelige effecten. ${ }^{85}$

De tweede verweten gedraging betrof dat Funda een hoger tarief in rekening brengt voor VBO-makelaars dan voor NVM-makelaars. Funda brengt aan VBO-makelaars een tarief van $€ 160$ in rekening voor een plaatsing op haar website ten opzichte van $€ 25$ voor NVM-makelaars. Hier staat echter tegenover dat de kosten voor een makelaar om zich bij NVM aan te sluiten een stuk hoger zijn dan bij VBO. ${ }^{86}$ Het gerechtshof neemt wederom het $M E O$-arrest tot uitgangspunt, en overweegt dat tariefdifferentiatie alleen tot een concurrentienadeel kan leiden indien de kosten die uit de tariefdifferentiatie voortvloeien significant zijn. Daarvan is in deze zaak niet gebleken volgens het gerechtshof. NVM mag in beginsel een voordeel voor haar leden bewerkstelligen, en het is aan VBO om aan te tonen dat de tariefdifferentiatie de grens van het toelaatbare overschrijdt en tot een concurrentienadeel leidt dat kwalificeert als verboden discriminatie. Daarvoor had VBO meer inzicht moeten geven in informatie als omzet- en kostenstructuur, opbouw van courtage, het belang van de hoogte van de courtage en de uitwerking op lokale makelaarsmarkten, aldus het gerechtshof. ${ }^{87}$ Ook deze verweten gedraging wordt aldus als onvoldoende onderbouwd afgewezen.

\section{Verticale afspraken}

Verticale afspraken hebben inmiddels een vaste plek in de kroniek civiele rechtspraak mededingingsrecht veroverd. Ook in 2020 was er een drietal uitspraken over dit onderwerp die vermelding in deze kroniek verdienen. ${ }^{88}$

83. Hof Amsterdam, VBO c.s./Funda C.S., r.o. 3.12.1.

84. De rechtbank had de deskundigen gevraagd om met een bericht te komen inzake het bestaan van een machtspositie van Funda, niet inzake eventueel misbruik, zie r.o. 3.10. Zie voor enkele kanttekeningen bij het leunen van de rechter op een deskundigenbericht bovengenoemd artikel van Mulder.

85. Hof Amsterdam, VBO c.s./Funda c.s., r.o. 3.13.

86. De kosten van een dergelijk lidmaatschap zijn niet vermeld in het arrest maar bedragen bij NVM kennelijk $€ 15.000$ voor de aansluiting van een eerste vestiging.

87. Hof Amsterdam, VBO c.s./Funda C.S., r.o. 3.21.

88. Zie ook: Rb. Den Haag 25 februari 2020, ECLI:NL:RBDHA:2020:1600 (Nortic Fire/Pelletkachel Lemmer). 
De eerste uitspraak die wij bespreken, doet sterk denken aan het (inmiddels standaard)arrest Batavus/Vriend. ${ }^{89}$ Ook in deze zaak probeerde een fietsenproducent, Trek, de distributieovereenkomst met een van haar dealers te beëindigen. Trek wilde dit doen omdat de dealer de fietsen met flinke korting via internet verkocht en deze ongeassembleerd leverde. ${ }^{90}$ De trouwe lezers van deze kroniek zal het niet verbazen dat deze handelswijze, in de woorden van Trek 'tot onrust heeft geleid bij collega Trek-dealers'. 91

De dealer stapte vervolgens naar de voorzieningenrechter van de rechtbank Amsterdam om nakoming van de distributieovereenkomst te vorderen. De voorzieningenrechter acht het bewezen dat Trek druk op haar dealers uitoefent om een minimumprijsniveau te garanderen, en zich daarmee schuldig maakt aan (verboden) verticale prijsbinding. ${ }^{92}$ Daarentegen kwalificeert de voorzieningenrechter Treks eis dat de dealer fietsen alleen geassembleerd in de winkel mag overhandigen niet als een illegale restrictie van passieve verkoop. ${ }^{93}$ Volgens de voorzieningenrechter mag Trek op kwaliteitsgronden de voorwaarde stellen dat de dealer na een internetverkoop de fiets ter plekke assembleert en afstelt. ${ }^{94}$

Omdat de dealer fietsen ongeassembleerd had geleverd, oordeelt de voorzieningenrechter dat de opzegging van de distributieovereenkomst niet onregelmatig is. Wel is hij van oordeel dat het, gezien de lange duur van de overeenkomst, in strijd met de redelijkheid en billijkheid is dat Trek de overeenkomst per direct heeft beëindigd. ${ }^{95}$ De voorzieningenrechter gebiedt Trek daarom om de distributieovereenkomst na te komen totdat deze op 26 juni 2021 afloopt.

De tweede zaak betreft een kort geding tussen de merkhouder van Woezel \& Pip, Dromenjager, en haar licentienemer International Bon Ton Toys (IBTT). ${ }^{96}$ IBTT had een licentie van Dromenjager om Woezel \& Pipknuffels te produceren. Volgens de licentieovereenkomst mocht zij deze knuffels echter alleen maar verkopen aan door Dromenjager goedgekeurde afnemers. Verder hadden partijen afgesproken dat IBTT toestemming zou vragen voor het houden van kortingsacties en daarbij een korting van maximaal 25\% zou hanteren. Toen Dromenjager weigerde om er goedkeuring aan te geven dat IBTT haar voorraad knuffels aan Kruidvat verkocht, stapte IBTT naar de rechter.

De voorzieningenrechter van de rechtbank Amsterdam overweegt dat Dromenjager geen selectief of exclusief distributiestelsel hanteert, en is het eens met IBTT dat

89. HR 6 september 2011, ECLI:NL:HR:2011:BQ2213 (Batavus/Vriend). Zie Tuinenga \& Kortmann 2012, p. 55-65 en P.J. Kreijger, 'De onvermoede reikwijdte van de mededingingsrechtelijke nietigheid', MvV 2011, p. 305-314.

90. Rb. Amsterdam 22 december 2020, ECLI:NL:RBAMS:2020:6973 (X/ Trek).

91. X/Trek, r.o. 2.8

92. $X /$ Trek, r.o. 4.17

93. $X /$ Trek, r.o. 4.21

94. $X /$ Trek, r.o. 4.22

95. $X /$ Trek, r.o. 4.24

96. Rb. Amsterdam 8 oktober 2020, ECLI:NL:RBAMS:2020:4908 (IBTT/ Dromenjager). de goedkeuringsplicht van Dromenjager een klantenbeperking is die kwalificeert als hardcorebeperking onder artikel 4 onder b Groepsvrijstellingsverordening Verticalen $(\mathrm{GVV}) .{ }^{97}$ De door partijen afgesproken maximumkorting kwalificeert de rechtbank eveneens als hardcorebeperking, namelijk als verticale prijsbinding in de zin van artikel 4 onder a GVV. De rechtbank overweegt ook, met verwijzing naar het Expedia-arrest, ${ }^{98}$ dat bij een hardcorebeperking uitgegaan moet worden van een merkbare beïnloeding. Om deze reden kan de beperking ook niet onder de De Minimis-mededeling van de Europese Commissie vallen. ${ }^{99}$

De voorzieningenrechter oordeelt daarom dat de desbetreffende bepalingen van de licentieovereenkomst nietig zijn. De overeenkomst blijft verder in stand, omdat de nietige clausules geen ondeelbare eenheid vormden met de rest van de overeenkomst. ${ }^{100}$ Als de licentieovereenkomst volledig nietig zou zijn, zou dit bovendien als ongewenst gevolg hebben dat IBTT niet langer de Woezel \& Pip-merken mocht gebruiken (en daardoor de knuffels nog steeds niet kon verkopen).

Tot slot bespreken wij het arrest van het gerechtshof Amsterdam in Action Sport/Nike ${ }^{101}$ Action Sport is een Italiaanse sportartikelenwinkel gevestigd op Sicilië. Zij had een distributieovereenkomst voor Nike-producten met Nike European Operations Netherlands B.V. (Nike Europe), onderdeel van het Amerikaanse Nike-concern. Nike Europe hanteert een selectief distributiestelsel. Action Sport verkocht de Nike-producten mede via het platform Amazon, een partij die niet door Nike Europe is geautoriseerd als distributeur. Nadat Nike Europe enkele malen tevergeefs Action Sport had gesommeerd de verkoop via Amazon te staken, heeft zij de distributieovereenkomst met Action Sport ontbonden.

In eerste aanleg oordeelde de rechtbank Amsterdam dat de opzegging niet in strijd was met het mededingingsrecht. ${ }^{102}$ Het gerechtshof laat deze uitspraak in stand. Het overweegt dat in een selectief distributiestelsel internetverkoop via bepaalde kanalen mag worden verboden, ook in een situatie dat het om nietluxe producten gaat. ${ }^{103}$ In dit geval gold geen algeheel verbod op internetverkoop, want het was Action Sport wel toegelaten om bijvoorbeeld via het platform van Zalando te verkopen. ${ }^{104}$

De stelling van Action Sport dat Nike in de Verenigde Staten zelf producten via Amazon verkocht, kon haar ook niet baten. Het gerechtshof acht deze stelling onvoldoende onderbouwd, en overigens ook niet ter zake

97. IBTT/Dromenjager, r.o. 4.12

98. HvJ EU 13 december 2012, zaak C-226/11, ECLI:EU:C:2012:795, NJ 2013, 253 (Expedia).

99. Expedia, r.o. 4.8.

100. Expedia, r.o. 4.13

101. Hof Amsterdam 14 juli 2020, ECLI:NL:GHAMS:2020:2004 (Action Sport/Nike). Het arrest is inmiddels niet meer beschikbaar op rechtspraak.nl. Deze publicatie is om de auteurs onbekende redenen ingetrokken.

102. Rb. Amsterdam 4 oktober 2017, ECLI:NL:RBAMS:2017:7282 (Nike/ Action Sport).

103. Rb. Amsterdam, Nike/Action Sport, r.o. 3.7.6-3.7.7.

104. Rb. Amsterdam, Nike/Action Sport, r.o. 3.7.8. 
doen omdat het niet Nike Europe betrof maar haar Amerikaanse zustermaatschappij. Het gerechtshof concludeert dat Action Sport niet aan haar stelplicht heeft voldaan, waarop haar grieven tegen de uitspraak stranden. Auteurs merken op dat in Duitsland een striktere lijn wordt gehanteerd met betrekking tot internetverkooprestricties, zoals blijkt uit vergelijkbare zaken tegen Adidas en Asics. ${ }^{105}$ De visie van het Bundeskartellamt houdt in dat retailers in beginsel de mogelijkheid moeten hebben om hun producten via open internetplatforms te verkopen om hun afzetmogelijkheden te verbreden. ${ }^{106}$ Dit is met name van belang voor kleinere retailers die niet de capaciteit hebben om hun eigen website te creëren.

\section{Besluit ondernemingsvereniging}

Hoewel de meeste mededingingsrechtelijke procedures in 2020 over overeenkomsten en gedragingen van ondernemingen gingen, was er één zaak waarbij de rechtsgeldigheid van een besluit van een ondernemingsvereniging in twijfel werd getrokken. Dit betreft de beslissing van de Koninklijke Nederlandse Voetbalbond (KNVB) dat voetbalclubs in 2020 niet kunnen promoveren naar de eredivisie en ook niet kunnen degraderen naar de eerste divisie. Deze beslissing was ingegeven door het feit dat de overheid professionele voetbalwedstrijden had verboden als onderdeel van haar COVID-maatregelenpakket. Twee voetbalclubs uit de eerste divisie, Cambuur en De Graafschap, waren het niet eens met de door de KNVB gekozen oplossing en startten een kort geding.

Hun vordering baseerden zij onder meer op een schending van artikel $6 \mathrm{Mw}$. De voorzieningenrechter van de rechtbank Midden-Nederland overweegt dat het in dit geval gaat om een zeer uitzonderlijke situatie. Zij vraagt zich dan ook af of het mededingingsrecht in deze situatie wel van toepassing is, en oordeelt dat dit in kort geding niet vastgesteld kan worden. ${ }^{107}$ Desalniettemin bevat de uitspraak een korte mededingingsrechtelijke analyse. Volgens de voorzieningenrechter lijkt er op het eerste gezicht een rechtvaardiging voor het besluit van de KNVB te zijn. Bovendien heeft het eenmalig niet kunnen toetreden tot de eredivisie niets te maken met het uitschakelen van concurrentie zoals in de door Cambuur en De Graafschap aangehaalde $I S U$-zaak aan de orde was. ${ }^{108}$

\section{Non-concurrentiebedingen}

Dit jaar waren er, zoals gebruikelijk, ook weer een aantal uitspraken over concurrentie- en relatiebedingen. ${ }^{109} \mathrm{Wij}$ bespreken er een over een non-concurrentiebeding in een maatschapsovereenkomst van een tandartsenpraktijk. ${ }^{110}$ Toen de eiseres in deze procedure zich wilde aansluiten bij een andere tandartspraktijk, beriep de maatschap zich op het non-concurrentiebeding in de maatschapsovereenkomst. Deze had echter een duur van tien jaar. In kort geding vorderde de eiseres daarom schorsing van het non-concurrentiebeding.

De voorzieningenrechter is het met de eiseres eens dat het non-concurrentiebeding wegens strijd met het mededingingsrecht nietig is. Volgens de voorzieningenrechter gaat het om een strekkingsbeperking, omdat het enkele doel van het beding is om te voorkomen dat een vertrekkende tandarts in concurrentie met de maatschap zou treden. ${ }^{111}$ Onder verwijzing naar de Mededeling Nevenrestricties $^{112}$ oordeelt de voorzieningenrechter voorts dat de duur van het beding verder gaat dan redelijkerwijs noodzakelijk kan worden geacht.

\section{Bestuurdersaansprakelijkheid}

Als hekkensluiter van deze kroniek bespreken wij een uitspraak waarin een voormalig bestuurder van Heiploeg aansprakelijk wordt gehouden voor de betaling van een (gedeelte van) de aan de onderneming opgelegde kartelboete voor het garnalenkartel. Voor zover de auteurs weten, is dit de eerste keer dat in Nederland een kartelboete succesvol wordt verhaald op een (oud-)bestuurder. 113

De gedaagde was tot 2 augustus 2004 (indirect) bestuurder van vier vennootschappen van het Heiploegconcern, waaronder Heiploeg B.V. en Heiploeg Beheer B.V. In die hoedanigheid was gedaagde betrokken bij het door de Commissie opgerolde garnalenkartel, dat van 21 juni 2000 tot 13 januari 2009 duurde. ${ }^{114}$ Hiervoor legde de Commissie in 2013 een boete van meer dan $€ 27$ miljoen op aan Heiploeg B.V. en Heiploeg Beheer B.V. en haar moedermaatschappijen. Daarbij stelde de Commissie vast dat Heiploeg B.V. en Heiploeg Beheer B.V. rechtstreeks hadden deelgenomen hadden aan het kartel. Niet lang daarna ging het Heiploegconcern failliet.

De curatoren van Heiploeg probeerden het boedeltekort en de kartelboete vervolgens op de bestuurders en commissarissen van het concern te verhalen. Met een aantal werd een schikking getroffen. Omdat gedaagde nul op het rekest gaf, dagvaardden de curatoren hem

109. Zie ook: Rb. Rotterdam 26 februari 2020, ECLI:RBROT:2020:1604.

110. Rb. Overijssel, ECLI:NL:RBOVE:2020:1242 (X/Maatschap voor Mondziekten, Kaak- en Aangezichtchirurgie).

111. X/Maatschap voor Mondziekten, Kaak- en Aangezichtchirurgie, r.o. 4.8.

112. Mededeling van de Commissie betreffende beperkingen die rechtstreeks verband houden met en noodzakelijk zijn voor de totstandbrenging van concentraties, PbEU 2005, C 56/24.

113. Vgl. Rb. Rotterdam 7 maart 2007, ECLI:NL:RBROT:2007:BA0926 (CEF City Electrical Factors B.V./X), waarin een beroep op externe bestuurdersaansprakelijkheid afketste op verjaring.

114. Commissiebeschikking 27 november 2013, zaak AT.39633 (Garnalen). 
voor de rechtbank Noord-Nederland. Zij betoogden dat hij onrechtmatig had gehandeld jegens de gezamenlijke schuldeisers van Heiploeg B.V. en Heiploeg Beheer B.V. en daardoor uit hoofde van artikel 6:162 Burgerlijk Wetboek (BW) aansprakelijk is voor het boedeltekort van deze vennootschappen (de 'Peeters/Gatzenvordering'). Daarnaast stelden zij dat gedaagde aansprakelijk was jegens Heiploeg B.V. en Heiploeg Beheer B.V. voor de kartelboete omdat hem als bestuurder een ernstig verwijt gemaakt kon worden ex artikel 2:9 BW. Later hebben de curatoren hun eis in die zin verminderd, dat zij verzochten om de schadevergoeding te verminderen met de bijdrageplicht van de bestuurders en toezichthouders met wie zij een schikking getroffen hebben.

De rechtbank overweegt dat gedaagde langdurig, direct en persoonlijk betrokken was bij de gedragingen van Heiploeg B.V. en Heiploeg Beheer B.V. om de in- en verkoopprijs van Noordzeegarnalen te beïnvloeden. ${ }^{115}$ Daarmee is volgens de rechtbank sprake van een ernstig verwijt omdat voldaan is aan de voorwaarde van geobjectiveerde wetenschap dat zijn daad leidt tot het verzaken van verplichtingen door de rechtspersoon. ${ }^{116}$

De rechtbank wijst de Peeters/Gatzen-vordering af omdat de curatoren het causale verband tussen de onrechtmatige daad van de gedaagde en het failleren van Heiploeg niet hebben aangetoond. Het ging al geruime tijd slecht met Heiploeg, zodat het goed mogelijk is dat Heiploeg ook failliet was gegaan als de boete niet was opgelegd. ${ }^{117}$ Daarentegen achtte de rechtbank de vorderingen op grond van onbehoorlijk bestuur wel toewijsbaar. In dit geval is er namelijk wel causaal verband tussen de onbehoorlijke taakvervulling als bestuurder (het bevorderen van het kartel) en de door Heiploeg B.V. en Heiploeg Beheer B.V. geleden schade (de boete). ${ }^{118}$ De vordering is ook niet verjaard, oordeelt de rechtbank. De verjaring is begonnen te lopen drie maanden na de kennisgeving van het boetebesluit, omdat dat het moment was dat de boete diende te worden betaald. Daarna was de verjaring tijdig gestuit door middel van een aanmaning en het uitbrengen van de dagvaarding. ${ }^{119}$ Uiteindelijk hoeft gedaagde niet de volledige boete te vergoeden. Ten eerste is hij maar aansprakelijk voor een

115. Rb. Noord-Nederland 23 september 2020, ECLI:RBNNE:2020:3292 (Breuker q.q./X), r.o. 4.28-4.30.

116. Breuker q.9./X, r.o. 4.29, met verwijzing naar HR 8 december 2006 ECLI:NL:HR:2006:AZ0759 (Ontvanger/Roelofsen). Overigens past de rechtbank het tweede door de Hoge Raad in Ontvanger/Roelofsen geformuleerde criterium, namelijk dat er geobjectiveerde wetenschap is dat de rechtspersoon geen verhaal biedt voor schade als gevolg van het niet-nakomen van de desbetreffende verplichting, niet toe. De rechtbank overweegt dat dit een additionele voorwaarde betreft die alleen geldt wanneer de rechtspersoon vorderingen onbetaald en onverhaalbaar laat. In dit geval heeft de bestuurder toegestaan dat de rechtspersoon zich schuldig maakte aan een zeer ernstige normschending, waarbij er een risico op draconische boetes en ernstige financiële en reputatieschade bestond. In deze situatie is het voor het vaststellen van een ernstig verwijt niet nodig dat de bestuurder ook wist dat de rechtspersoon geen verhaal biedt.

117. Breuker q.q./X, r.o. 4.37.

118. Breuker q.q./X, r.o. 4.57.

119. Breuker q.q./X, r.o. $4.43-4.45$ deel van de boete, omdat hij ook maar tijdens een deel van de kartelperiode bestuurder was. ${ }^{120}$ Ten tweede vermindert de rechtbank de door gedaagde te bepalen schadevergoeding met de bijdrageplicht van de bestuurders en commissarissen met wie de curatoren reeds geschikt hadden. ${ }^{121} \mathrm{Zij}$ doet echter geen uitspraak over de hoogte van de bijdrageplicht van deze derden. Hierdoor lijkt het vonnis lastig te executeren, waardoor de mogelijkheid bestaat dat de curatoren vooralsnog achter het net vissen. 